\title{
Plans for giant freshwater pond opposed by Japanese
}

\section{Tokyo}

TWENTY years ago the Japanese Ministry of Agriculture, Forestry and Fisheries started a project to turn the inland

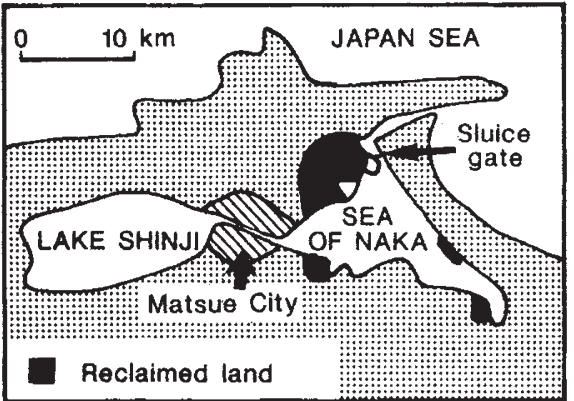

Sea of Naka and a brackish lake on the Japan Sea coast into a gigantic freshwater pond for watering rice paddy fields that were to be established on land reclaimed from Naka Sea. In the immediate postwar period when there was a food shortage in Japan, the plan made some sense, but two years after the project got under way a rice reduction policy came into effect to curb rice oversupply. Nevertheless, the ministry has forged ahead and sunk hundreds of millions of dollars into land reclamation and the building of a gigantic set of sluice gates at the mouth of Naka Sea. And next September the ministry plans to close the gates. But conservationists, fishermen and a majority of the local people are opposed to the plan because it will destroy a productive local fishery and will probably have devastating environmental effects on one of Japan's few remaining brackish lakes.

The plan to "desalinize" Naka Sea and Lake Shinji on the border of Shimane and Tottori Prefectures dates back to the 1920s when the channel linking the lake and Naka Sea was widened and deepened to allow passage of ferries. Seawater and marine life flooded into the already brackish lake and the local fishing industry boomed. But farmers complained that the saltier water was damaging their rice fields and they called for the mouth of Naka Sea to be dammed. However, it was not until the advent of a food shortage after the war that the ministry began to lay plans and the project finally got under way in 1968 .

Over 2,500 hectares of land have been reclaimed at a cost of 72,000 million yen (\$576 million). And the ministry has won another $¥ 6,000$ million in fiscal year 1988 to close the gate and develop some of the reclaimed land-apart from a trial attempt to grow a few cabbages, the land remains unused.

Shutting off the supply of seawater will destroy a local fishery for sea bass and shimeji clams that earns more than $¥ 3,000$ million ( $\$ 23$ million) a year. There are also fears that thousands of wild duck and geese which overwinter around the lake and sea will be endangered because they feed on the tiny shimeji clams that abound in the brackish waters of Lake Shinji. And restriction of circulation and accumulation of nutrients may lead to suffocating algal blooms, such as occur in a former brackish lake north of Tokyo that was similarly shut off from the sea.

In February 10,000 people linked hands around Lake Shinji in protest and opinion polls indicate 70 per cent opposi-

tion to the ministry's plan to close the gate. During recent budget deliberations in the Diet, Prime Minister Noboru Takeshita who represents the Shimane area said that he "cannot ignore the reality that the local people's need has changed greatly since the start of the project". And the secretary general of the Shimane Prefecture association of the ruling Liberal Democratic Party has suggested that some of the reclaimed land could be converted into a golf course.

But, apart from a compromise proposal to leave one of the ten sluice gates open for a trial period, the ministry is determined to shut the gates. As one Shimane University professor put it, Japanese public works projects are run like the Japanese army; once the advance begins there can be no retreat.

David Swinbanks

\section{Leningrad library loses irreplaceable publications}

\section{London}

Atmost 400,000 books and periodicals, including rare and irreplaceable works, were destroyed in a fire last month at the Leningrad library of the Soviet Academy of Sciences. At the time of the fire, the library had been without an operational fire-alarm system for over four years. It was due to be coupled up to a new automatic alarm network on 1 February 1988. Unfortunately, the date was postponed when an engineer fell ill. On the evening of Sunday, 14 February, fire broke out in the stacks.

The fire initially attracted little public attention. Immediately after the fire, the director of the library, presumably in a state of shock, estimated the financial loss at about 3,000 roubles $(£ 3,000)$. On the basis of this, TASS announced that there had been partial damage to the newspaper holdings, but that "the country's treasure, the main archive of academic editions, rare manuscripts, exchange and specialized stocks and many other valuable items remained intact". Later investigation by $\mathrm{L}$. Tereshkin, a reporter from Leningradskaya Pravda, revealed that there was also considerable damage to the book holdings, including the famous Baer collection, bequeathed to the academy by the zoologist Karl Ernst Baer (1792-1876). Later estimates put the loss at 300,000 roubles, but even this, library staff feel, is almost certainly too low.

Almost half the works lost are of foreign origin, so that inflation will have an enormous effect on replacement costs. Only very rough estimates (by metres of shelving) have been made so far of the books damaged by scorching or water, and which will require extensive repair and salvage work. Academician Dmitrii Likhachev, the mediaeval historian who led the campaign against the diversion of the Siberian rivers, warned the annual general meeting of the Soviet Academy of Sciences last month that "the most urgent and resolute measures" will be needed if these books are to be saved. He estimated the priceless books lost as "several tens of thousands".

These works, however, Tereshkin says, have not been included in the estimated financial loss. Books and manuscripts which are "priceless", he says, are not even assigned a nominal price in the inventory, so that, he said, the library could have lost all its ancient manuscript collection and, according to the book-keeping now in force, have suffered no loss at all. The party and trade union organizations at the library have asked for a state commission to be appointed to produce an "objective" estimate of the losses. Leningrad's fire chief, Lieutenant-Colonel A.G. Ivanov, is also unhappy. Hardly any of the historic buildings and scientific collections within his precinct have proper fire alarm systems. The Institute of Archaeology, the Institute of Oriental Studies, the Academy of Fine Arts, the Cathedral of Saints Peter and Paul, the Zoological Museum, and the Museum of Ethnography, have no alarm system at all, while others have only outdated and nonautomatic systems. In 1986, he told Tereshkin, there was a major fire, in which several lives were lost, in the Yusupov palace. There was no alarm system at the time of the fire, and none has yet been installed. How much more will be needed, he asked, to rouse the city authorities from their complacency? Vera Rich 